\title{
Ploidy Mosaics - Does Endopolyploidy in Explants Affects the Cytogenetic Stability of Orchids Regenerated From PLBs?
}

Yohan Fritsche ( $\nabla$ yfritsche@gmail.com )

Federal University of Santa Catarina https://orcid.org/0000-0002-1048-071X

Thiago Sanches Ornellas

Federal University of Santa Catarina: Universidade Federal de Santa Catarina

\section{Valdir Marcos Stefenon}

Federal University of Santa Catarina: Universidade Federal de Santa Catarina

\section{Miguel Pedro Guerra}

Federal University of Santa Catarina: Universidade Federal de Santa Catarina

\section{Research Article}

Keywords: Protocorm-like bodies, endopolyploidy, flow cytometry, pollinia, cytochimera

Posted Date: November 11th, 2021

DOI: https://doi.org/10.21203/rs.3.rs-1035583/v1

License: (c) (i) This work is licensed under a Creative Commons Attribution 4.0 International License. Read Full License

Version of Record: A version of this preprint was published at Plant Cell, Tissue and Organ Culture (PCTOC) on January 22nd, 2022. See the published version at https://doi.org/10.1007/s11240-02202238-z. 


\section{Abstract}

The induction and regeneration of protocorm-like bodies (PLBs) is a morphogenetic pathway widely used for orchid micropropagation. As endopolyploidy, i.e., the coexistence of cells with different ploidy levels, is a common feature in orchid tissues, a natural question arises when using somatic tissues as explants for orchid micropropagation: does endopolyploidy in explants affect the cytogenetic stability of regenerated plantlets? To answer this question, Epidendrum fulgens was used as a model plant, and flow cytometry (FC) was used to analyze endopolyploidy in pollinia, petals, labella, leaf bases, leaf tips, root tips, protocorms bases and protocorms apexes, which were subsequently used as explants for PLB induction and plant regeneration. The ploidy screening showed contrasting ploidy patterns in the samples. Endopolyploidy was detected in all tissues, with C-values ranging from $1 \mathrm{C}$ to $16 \mathrm{C}$. Protocorm bases and root tips presented the highest proportion of endopolyploidy, while petals and protocorm apexes showed the lowest proportion. Flower parts presented high oxidation for PLB induction and pollinia failed to produce PLB or callus. The highest induction rate was observed at $10 \mu \mathrm{M} T \mathrm{TZ}$, with $92 \%, 22 \%$, and $0.92 \%$ for protocorm bases, leaves, and root tips, respectively. Plantlets were more easily regenerated from PLBs induced from protocorm bases than from leaves and roots. Doubled ploidy levels were registered in a proportion of $11 \%$ and $33 \%$ for PLB-regenerated plantlets obtained from protocorm bases and leaf bases, respectively, which was not directly associated with the proportion of endopolyploid cells or cycle value of explants.

\section{Introduction}

Endopolyploidy is a cell cycle variant characterized by successive DNA duplication events without chromosome segregation and cell division (Edgar et al. 2014). Endopolyploidy canresult from two different processes, namely endocycle and endomitosis (see Leitch and Dodsworth 2017 for details), both of them culminating with cells with different ploidy levels within the same tissue or organism (Barow and Meister 2003). It was only after the advent of flow cytometry that it was possible to recognize the importance of such duplication events limited to specific cells or tissues (Bateman et al. 2018).

Endopolyploidy is responsible for controlling many developmental processes in plants, as the growth rate (Barow and Meister 2003), the cell size (Maluszynska et al. 2013), the resistance to herbivory (Mesa et al. 2019), and the adaptation to climate variation (Pacey et al. 2020). One obvious feature of endoreduplicated cells is the overexpression of genes (e.g., Barow 2006; Lee 2009; Leitch and Dodsworth 2017), leadings to different physiological and developmental processes. Therefore, endopolyploidy appears to be a mechanism to control cell function, although the molecular mechanisms of such processes are unknown (Brown et al. 2017).

Endopolyploidy is a common feature in eukaryotes in general, but it prevails in plants (Leitch and Dodsworth 2017). In orchids, it appears to be extremely frequent, and many studies have already detected such feature (e.g., Fukai et al. 2002; Lim and Loh 2003; Yang and Loh 2004; Teixeira da Silva and Tanaka 2006; Ho et al. 2016; Bateman et al. 2018). 
Such ploidy mosaics are even more complicated in orchids, as cells can undergo a unique type of endopolyploidy known as progressive partial endoreplication (PPE), a feature unique of the Orchidaceae (Trávníček et al. 2019). PPE leads to the coexistence of cells with different and non-multiple DNA contents in the same tissue and may occur in all orchid subfamilies except for Apostasioideae (Trávníček et al. 2015; Brown et al. 2017).

Therefore, an obvious question arises when using somatic tissues as explants for micropropagation: does the pre-existing ploidy variation in the cells of explants affects the cytogenetic stability of regenerated plants?

The induction of protocorm-like bodies (PLB) is a morphogenetic pathway used for orchid micropropagation. The terminology was first used by Morel in 1960 (Arditti 2009) to describe their structural similarity to orchid protocorms. It is a promising technique that could replace conventional micropropagation as it allows the clonal conservation, breeding, and propagation of elite plants with high phytosanitary quality (Cardoso et al. 2020), and are excellent targets for genetic transformation (Liu et al. 2019; Hsieh et al. 2020). Orchid micropropagation protocols adopt many different types of explants, as roots (Kerbauy and Estelita 1996; Picolotto et al. 2017), floral stalks (Chen et al. 2002), leaves (Chen and Chang 2006), and shoot tips (Roy et al. 2007), but whether the use of such variable explant sources may lead to variations on regenerated plantlets is still an open issue. Hence, the accurate knowledge of the endopolyploidy status of the entire plant is crucial to select explants for tissue culture, and knowing whether the use of explants with different endopolyploid patterns may affect regenerated plants is necessary not only to avoid somaclonal variation (Bairu et al. 2011) but also as a tool for genetic improvement.

The objective of the present work was to perform a screening of the ploidy levels of different orchid organs and tissues, to develop PLB induction protocols using explants with contrasting ploidy patterns, and to elucidate the influence of the pre-existing explants' ploidy variation on the cytogenetic stability of regenerants.

\section{Material And Methods}

\section{Endopolyploidy screening of explants}

Natural populations of Epidendrum fulgens Brongn (Orchidaceae) were sampled in the Restinga vegetation of the Atlantic rainforest in Florianópolis, $\left(27^{\circ} 46^{\prime} 50.74^{\prime \prime S}\right.$ and $48^{\circ} 29^{\prime} 11.98^{\prime \prime} \mathrm{W} ; 27^{\circ} 39^{\prime} 2.15^{\prime \prime S}$ and $48^{\circ} 28^{\prime} 6.25^{\prime \prime} \mathrm{W} ; 27^{\circ} 37^{\prime} 25.02^{\prime \prime S}$ and $\left.48^{\circ} 27^{\prime} 18.05^{\prime \prime} \mathrm{W}\right)$. Vegetative offshoots, produced in the floral stalks, were carefully removed from healthy plants of each population and transplanted to $2 \mathrm{~L}$ pots containing a mix of autoclaved sand and commercial substrate (Tropstrato HT®) in a 1:1 ratio. These plants were used as the source of materials for the present study. For obtaining in vitro plantlets, E. fulgens seeds were harvested from mature pods, sterilized, and sown as described by Voges et al. (2014). 
Flow cytometry (FC) was used to analyze the endopolyploidy level of the following organs/tissues: Pollinia, petals, labella, root tips, leaf basal region, leaf tips, protocorm bases, and protocorm apex. Pisum sativum cv. Ctirad (Fabaceae) $(2 \mathrm{C}=9.09 \mathrm{pg}$ DNA) was used as an internal reference standard for the flow cytometry analysis. Seeds of $P$. sativum were kindly provided by $\mathrm{Dr}$. Jaroslav Doležel from the Institute of Experimental Botany of the Czech Academy of Sciences. Nuclei from the samples and leaves of the reference standard $(\sim 50 \mathrm{mg})$ were simultaneously extracted by chopping with a razor blade (Galbraith et al. 1983) on $2 \mathrm{~mL}$ ice-cold Otto-l buffer (Otto 1990). The nuclei suspension was filtered through a $40 \mu \mathrm{m}$ nylon mesh (BD Falcon) and centrifuged at $150 \mathrm{~g}$ for $5 \mathrm{~min}$. The supernatant was removed with a pipette and the pellet was resuspended after the addition of $100 \mu \mathrm{L}$ of fresh ice-cold Otto-I buffer. The nuclei suspension was stained in the dark for $30 \mathrm{~min}$ in $500 \mu \mathrm{L}$ of Otto-II buffer (Otto 1990) supplemented with $50 \mathrm{\mu g} \mathrm{mL}^{-1}$ of propidium iodide (Pl; Biotium) and RNase-A (SigmaAldrich).

PI fluorescence was measured with a BD FACSCanto ${ }^{T M}$ II flow cytometer, equipped with an Argon Laser $(488 \mathrm{~nm})$, at the Laboratório Multiusuário de Estudos em Biologia, Federal University of Santa Catarina (LAMEB/UFSC). The position of the peaks from the samples and the reference standard was settled by analyzing the first run with each sample separately. The $\mathrm{G} 1$ peaks were assigned to a specific channel and the equipment voltage and gain were kept constant throughout the analyses.

Flowing software 2.5.1 was used to process the data. First, we analyzed dot-plots of fluorescence intensity on a linear scale vs. forward scatter light on a logarithmic scale. A polygonal region including all Pl-stained nuclei was created on the dot-plots, from which gated histograms of fluorescence intensity in linear scale were created. Linear gated regions were created on histograms to obtain statistics of intact nuclei only.

The numbers of endopolyploid nuclei were used to calculate the cycle value (Barow and Meister 2003), with the formula:

Cycle value $=\frac{(0 \times n 2 C+1 \times n 4 C+2 \times n 8 C+3 \times n 16 C)}{(n 2 C+n 4 C+n 8 C+n 16 C)}$

Where, $n$ is the number of nuclei with C-values of $2 C, 4 C, 8 C$, and $16 C$, respectively.

The genome size was calculated based on the ratio between the $2 \mathrm{C}$ fluorescence intensity peaks from the samples and the internal reference standard. The value was multiplied by the DNA C-value of the reference standard (Doležel and Bartoš 2005). To convert DNA content in picograms (pg) to base pairs (bp), we considered $1 \mathrm{pg}=0.978 \times 10^{9}$ bp (Doležel et al. 2003).

\section{Protocols for PLB induction and plantlet regeneration}

Experiments for PLB induction were performed using all the organs/tissues used on the endopolyploidy analysis. They are described separately below. 


\section{PLB induction using flower parts as explants}

Flower buds were collected before anthesis and superficially sterilized with ethanol $70 \%$ for $1 \mathrm{~min}$ and sodium hypochlorite $0.5 \%$ for 5 min, followed by 3 rinses in sterile distilled water. Buds were opened under sterile conditions and the petals, labella, and pollinia were excised. Explants were inoculated in Petri dishes containing $25 \mathrm{~mL}$ of half-strength MS medium (Murashige and Skoog 1962) supplemented with $20 \mathrm{~g} \mathrm{~L}^{-1}$ sucrose, $250 \mathrm{mg} \mathrm{L}^{-1}$ polyvinylpyrrolidone (PVP), and different concentrations of plant growth regulators (PGR). The PGR compositions were the four different treatments of the experiment: (i) $20 \mu \mathrm{M}$ Thidiazuron (TDZ), (ii) $30 \mu \mathrm{M}$ TDZ, (iii) $9.3 \mu \mathrm{M}$ 2-isopentenyladenine (2iP) + $36 \mu \mathrm{M}$ 2,4-

Dichlorophenoxyacetic acid (2,4-D), and (iv) control medium without PGR.

Petals and pollinia were inoculated intact. Labella were cut in half, and ovaries were sliced in $1 \mathrm{~mm}$ thin cell layers (TCL). The numbers of explants inoculated per treatment were 32 for pollinia and labella and 64 for petals. Each explant was considered as a repetition. After 60 days of the inoculation, data of PLB induction and oxidation rates were collected. For pollinia, the length of the pollen tube was also measured.

\section{Defining the best TDZ concentration for PLB induction from leaf explants}

Leaves from in vitro plantlets were used to define the optimal concentration of PGR for PLB induction. Then, roots and protocorm bases were inoculated on this optimal concentration to compare the induction rate between the three different explants, as described below.

For obtaining in vitro plantlets, E. fulgens seeds were harvested from mature pods, sterilized, and sown as previously described. After four months of sown, plantlets with 4-5 leaves and roots were selected to extract leaf explants. Leaves $(\approx 1 \mathrm{~cm})$ were inoculated with the abaxial face down in Petri dishes containing half-strength MS medium (Murashige and Skoog 1962), supplemented with $20 \mathrm{~g} \mathrm{~L}^{-1}$ sucrose and different concentrations of TDZ $(0 \mu \mathrm{M}, 3 \mu \mathrm{M}, 6 \mu \mathrm{M}, 9 \mu \mathrm{M}, 12 \mu \mathrm{M}$, and $15 \mu \mathrm{M})$. Eight leaves were inoculated per Petri dish and a minimum of 40 leaves per treatment. The Petri dishes were sealed and kept in the dark at $25 \pm 2{ }^{\circ} \mathrm{C}$.

\section{PLB induction using different explants}

The best TDZ concentration for leaves was used to induce PLB from protocorm base and root tips. The explants were obtained from the asymbiotic seed germination as previously described. After one month of sown, homogenous protocorms, with shoot apex and before the first leaf emission, were selected and used as explants. A $1 \mathrm{~mm}$ width TCL from the protocorm base was excised from each protocorm under sterile conditions and inoculated in test tubes containing $5 \mathrm{~mL}$ of MS medium supplemented with $20 \mathrm{~g} \mathrm{~L}^{-}$

${ }^{1}$ sucrose and $10 \mu \mathrm{M}$ TDZ. The apexes were discarded. Root tips and leaves $(\approx 1 \mathrm{~cm})$ were obtained from four-month-old in vitro plantlets, as previously described, and inoculated in test tubes with the same medium used for protocorm bases. A total of 109 root tips, 49 protocorm bases, and 32 leaves were inoculated. 


\section{Data analysis}

Eight weeks after inoculation, data from oxidation, PLB induction rates, and number of PLB per explant were collected. Statistical analysis was performed with generalized linear models (GLM) using binomial distribution and logit link function, considering explants as categorical, and growth regulator concentrations as explanatory variables. All GLM analyses and Figures were produced on the R environment ( $R$ Core Team, 2019) using the car (Fox and Weisberg 2011), MASS (Venables and Ripley 2002), and ggplot2 (Wickham 2016) packages.

\section{Microscopic features of primary and secondary PLB}

Leaves with PLB and PLB clusters were fixed in glutaraldehyde (2.5\%) in sodium phosphate buffer $(0.1 \mathrm{M}$, $\mathrm{pH} 7.2)$ for $24 \mathrm{~h}$ and then dehydrated in ethanol series (20\%, 40\%, 60\%, 70\%, $80 \%, 90 \%$ and $100 \%)$ for 30 min each. For light microscopy, samples were embedded with histo-resin (Leica Historesin, Germany) and block-polymerized. Transversal slices $(5 \mu \mathrm{m})$ were performed in a microtome, stained with toluidine blue (O'Brien et al. 1964) and analyzed in an BX-40 microscope (Olympus, Japan). For scanning electron microscopy, dehydrated samples were submitted to critical point drying (EM CPD 030/Leica, Germany), fixed in aluminum stubs with carbon tape, coated with gold/palladium (EM SCD 500/Leica, Germany), and examined on a scanning electron microscope (JEOL, JSM-6390LV) at LCME/UFSC.

\section{Cytogenetic stability of plants regenerated endopolyploid explants}

Induced PLBs were transferred to test tubes containing $10 \mathrm{~mL}$ of PGR-free MS medium supplemented with $1.5 \mathrm{~g} \mathrm{~L}^{-1}$ activated charcoal and maintained in a $16 \mathrm{~h}$ photoperiod at $25^{\circ} \mathrm{C} \pm 2{ }^{\circ} \mathrm{C}$. Subcultures were performed every 8 weeks, and plants were obtained after ca. 24 weeks.

The ploidy of plantlets regenerated from leaves, protocorm bases and root tips were analyzed with FC using the same methodology previously described. Their ploidy level was compared with P. sativum as an internal reference standard, and asymbiotically seed-derived plantlets were used as a control for ploidy level. PLB-regenerated plantlets obtained from leaves $(n=27)$, protocorm bases $(n=20)$ and root tips $(n=$ 1) were analyzed. Histograms presenting peaks with poor quality and high coefficients of variation ( $\geq$ $5 \%$ ) were discarded.

\section{Results}

\section{Endopolyploidy screening of explants}

The FC screening analysis showed that all organs and tissues analyzed were endopolyploid. Five different cytotypes were detected, with C-values ranging from $1 \mathrm{C}$ to $16 \mathrm{C}$ (Fig. 1). Cells with 1C DNA Cvalue were only observed in pollinia, which correspond to the haploid vegetative nuclei. In all other organs/tissues, cells with C-values ranging from $2 \mathrm{C}$ to $16 \mathrm{C}$ were observed, implying the occurrence of at 
least 3 endocycles. The ratios between fluorescence peaks were always 2.0, which corresponds to the conventional type of endoreduplication (Table 1).

Table 1

Flow cytometric profiles of different organs and tissues of Epidendrum fulgens

\begin{tabular}{|c|c|c|c|c|c|c|}
\hline \multicolumn{7}{|c|}{ Ratios between peaks } \\
\hline $\begin{array}{l}\text { Organ / } \\
\text { tissue }\end{array}$ & $\begin{array}{l}\text { Cycle } \\
\text { value }\end{array}$ & $\begin{array}{l}\text { 2C Sample / 2C P. } \\
\text { sativum }\end{array}$ & $2 \mathrm{C} / 1 \mathrm{C}$ & $4 \mathrm{C} / 2 \mathrm{C}$ & $8 \mathrm{C} / 4 \mathrm{C}$ & $16 \mathrm{C} / 8 \mathrm{C}$ \\
\hline & $\begin{array}{l}\text { Mean } \pm \\
\text { s.d. }\end{array}$ & & & & & \\
\hline Pollinia & 0 & 0.317 & 1.965 & & & \\
\hline Petal & $\begin{array}{l}0.84 \pm \\
0.06\end{array}$ & 0.330 & & 1.987 & 1.989 & 2.051 \\
\hline Labellum & $\begin{array}{l}1.12 \pm \\
0.32\end{array}$ & 0.334 & & 1.984 & 1.979 & 2.050 \\
\hline Leaf tip & $\begin{array}{l}1.04 \pm \\
0.58\end{array}$ & 0.326 & & 2.000 & 1.974 & 1.970 \\
\hline Leaf base & $\begin{array}{l}1,27 \pm \\
0.28\end{array}$ & 0.330 & & 1.978 & 1.962 & 1.994 \\
\hline $\begin{array}{l}\text { Protocorm } \\
\text { base }\end{array}$ & $\begin{array}{l}1.47 \pm \\
0.68\end{array}$ & 0.340 & & 1.979 & 1.983 & 1.857 \\
\hline $\begin{array}{l}\text { Protocorm } \\
\text { apex }\end{array}$ & $\begin{array}{l}0.70 \pm \\
0.23\end{array}$ & 0.328 & & 1.977 & 1.984 & 1.970 \\
\hline Root tip & $\begin{array}{l}1.68 \pm \\
0.22\end{array}$ & 0.321 & & 2.021 & 1.968 & 1.960 \\
\hline
\end{tabular}

The proportion of each cytotype was variable among the different organs/tissues (Fig. 2). Cells with 16C DNA content were less frequent in petals and labellum (1.1\% and $2.6 \%$, respectively). In protocorm base, however, they represented $49.1 \%$ of cells. Root tips also contained higher numbers of $16 \mathrm{C}$ cells $(28.3 \%)$. On the other hand, $2 \mathrm{C}$ cells were scarce in the labellum (7.9\%), while on protocorm apex they correspond to more than half of the cytotypes. Noteworthy, the endopolyploidy pattern between protocorm apex and base regions was contrasting.

These differences in the proportion of cytotypes resulted in significantly different calculated cycle values (Table1). Protocorm bases presented the higher cycle value, followed by root tips. Leaf tip and leaf base presented intermediate values, while protocorm apex and petals exhibited cycle values lower than 1.0.

\section{Genome size estimation}

The nuclear genome size of Epidendrum fulgens calculated from the $2 \mathrm{C}$ peaks of all organs and tissues gave the same results, with a variation of only $2 \%$. The estimated DNA C-value was $1.492 \pm 0.031 \mathrm{pg}$ or 


\section{PLB induction using flower parts as explants}

The attempt to use flower parts as explants for PLB induction showed that using ex vitro flower buds was efficient in terms of asepsis. No contamination was observed on the introduced material (Fig. 3a). However, only one PLB was obtained from a labellum (Fig. 3b), although we could not multiplicate or regenerate it due to oxidation. Petals and labellum showed to be highly susceptible to early oxidation. Oxidation rates were $60 \%$ after two weeks of culture and $100 \%$ after four weeks (Fig. 3c).

On the other hand, pollinia were recalcitrant to oxidation and germinated in all treatments tested (Fig. 3ce). Neither the germination rate nor the pollen tube growth was affected by the treatments (Fig. 3f). Pollen tubes reached more than $2 \mathrm{~cm}$ in length after six weeks of inoculation (Fig. 3g). Nevertheless, no PLB or calli were obtained from pollinia or germinated pollen grains.

\section{PLB induction from leaves}

Leaves from young in vitro plantlets were responsive for PLB induction. Initial PLBs were observed after 4 weeks of culture (Fig. 4a-b). The PLBs were globular shaped, with a smooth surface, and were formed directly from the leaf tissue, without an intermediating callus (Fig. 4c). Eight weeks after inoculation, primary PLB elongated (Fig. 4d) and secondary PLB formed on the top and at the base of primary PLB (Fig. 4e). Histo-anatomical analysis showed that primary PLB had a main meristematic region as well as a secondary meristematic region localized at the base and close to the peridermis (Fig. 4f).

PLBs were induced on adaxial and abaxial leaf epidermis, mainly on the leaf base (Fig. $5 d$ ) and less frequently on leaf tips (Fig. 5c) or the top of the leaf blade (Fig. 5a-b). In the dark, PLBs were pale white with a smooth surface (Fig. 5e), and after being exposed to light they rapidly became dark green and initiated the production of leaf primordia (Fig. 5f). A complete representation of the PLB-to-plantlet regeneration process can be observed in Figure $5 \mathrm{~g}$.

\section{The best TDZ concentration for PLB induction}

The GLM analysis showed that PLB induction rate and average number of PLB per leaf explant varied according to TDZ concentration in culture medium (Fig. 6). PLB can be obtained from leaves even in medium without TDZ, at a low frequency and with a small number of PLB per explant, though. The PLB induction frequency showed a quadratic trend across the TDZ concentrations tested, with the higher induction rate estimated at $10 \mu \mathrm{M}$ (Fig. 6a).

On the other hand, the average number of PLB per leaf explant expanded linearly with increasing TDZ concentrations. The best-fitted model suggests that the number of PLB can be further increased when concentrations higher than $15 \mu \mathrm{M}$ are used, yet induction frequency decreases at concentrations higher than $10 \mu \mathrm{M}$ (Fig. 6b). Oxidation was not an issue for PLB induction from leaf explants, as the oxidation rates were the same across the TDZ concentrations tested (Fig. 6c). The obtained results suggest that in 
medium supplemented with $10 \mu \mathrm{M}$ TDZ, about $30 \%$ of PLB induction rate is obtained ( 22 to $40 \%$ ), with an average number of five PLB per explant.

\section{Comparison of PLB induction using leaves, root tips, and protocorm bases}

The comparison of PLB induction between explants with contrasting endopolyploid patterns showed highly variated responses. Protocorm bases were the most responsive explants for PLB induction, with more than $90 \%$ induction rate (Fig. $7 \mathrm{~g}$ ). PLBs were white and globular shaped when in the absence of light and were induced mainly from the protocorm base epidermal tissue (Fig. 7a). When exposed to light they became green and continued to proliferate (Fig. 7b). Plants were obtained after only one subcultivation step to PGR-free medium (Fig. 7c), which was faster than leaf-derived PLB, which demanded two or three subcultivation cycles.

Only one PLB was obtained from root tip explants (Fig. 7d-f) out of 109 inoculated root tips, which is less than $1 \%$ induction rate (Fig. $7 \mathrm{~g}$ ). The obtained PLB was induced from the calyptra region and was extremely slow-growing. We were able to regenerate a shoot from the root-derived PLB only after eight months of culture in PGR-free medium (Fig. 7f). Adventitious root and plantlet regeneration from the rootderived PLB took 15 months of culture. PLB induction rate on leaves was $22 \%$ (Fig. $7 \mathrm{~g}$ ), which is within the GLM analysis confidence envelope and shows that the previously obtained model was precise.

\section{Plantlet regeneration from PLB and cytogenetic stability}

Complete plant regeneration was considered after the observation of adventitious roots and the presence of fully expanded leaves. Regeneration took place after transferring PLB to PGR-free media under 16h photoperiod. It took 12,24 , and 60 weeks of culture to regenerate plantlets from PLB induced from protocorm bases, leaves, and root tips, respectively. The PLB-to-plantlet regeneration process was very similar to obtaining plants from seed germination. The difference is that plantlets were not individualized, but clustered, once that PLB clusters are not friable and easily separated from each other (Fig. 5).

Flow cytometry analysis of plants regenerated from PLB showed that some regenerants doubled their ploidy levels in relation to seed-derived plants, which were used as control (Fig. 8). Ploidy doubling was recorded in plantlets obtained from leaf and protocorm base PLBs. The single PLB-derived plantlet obtained from root tip PLB maintained the same ploidy level as the control plants.

Ploidy doubling was recorded at different proportions according to the explant source. Doubled ploidy regenerants were three times more frequent in plants regenerated from leaves than from protocorm bases. Plantlets with doubled ploidy levels corresponded to $11 \%$ and $33 \%$ of the plants regenerated from protocorm bases and leaves, respectively.

\section{Discussion}

Endopolyploidy is a common feature in E. fulgens organs and tissues, which results in different cycle values 
The purpose of this study was to gain a better understanding of the endopolyploid pattern in somatic tissues used for orchid micropropagation and its implication on the cytogenetic stability of regenerated plants. Whereas past researchers have found that $E$. fulgens is a diploid species $(2 n=2 x=24)$ (e.g., Felix and Guerra 2010; Assis et al. 2013), the present study has shown that endopolyploidy is a common feature in this species, which contributes to a growing body of evidence suggesting that endopolyploidy is widely distributed within flowering plants (Barow and Meister 2003). These results represent the first direct demonstration of endopolyploidy occurrence in its tissues, which we also showed that has important practical implications.

Unlike other studies, that focus on specific organs and tissues, our study provides a detailed map of endopolyploidy in virtually all somatic tissues that can be used as explants for PLB induction. Although endopolyploidy is present in the roots of Arabidopsis thaliana (Bhosale et al. 2018) and crop plants such as maize (Li et al. 2019) or potato (Laimbeer et al. 2017), there is not yet a consensus whether endopolyploid cells might be capable of regenerating plants by in vitro-induced morphogenetic pathways.

Interestingly, $\mathrm{FC}$ analysis of pollinia resulted in histograms with $1 \mathrm{C}$ and $2 \mathrm{C}$ peaks of fluorescence intensity. The $1 \mathrm{C}$ peak corresponds to the haploid vegetative nuclei from pollen grains, while the $2 \mathrm{C}$ peak is relative to generative nuclei in $2 \mathrm{C}$ state and $2 \mathrm{C}$ nuclei from surrounding somatic tissue (Trávníček et al. 2015). The $2 \mathrm{C}$ nuclei peaks may also represent diploid pollen nuclei, as they are quite frequent in orchids (Teoh 1984), or by grouped $1 \mathrm{C}$ nuclei that were not correctly isolated during sample preparation. The last hypothesis is less probable since no triads or tetrads were recorded on the FC histograms, which leads us to the conclusion that $E$. fulgens may produce a high number of diploid pollen grains. The analysis of pollinia serves as an accurate starting point to define the correct positions of the other cytotypes and to, undoubtedly, estimate the DNA C-value, as $2 \mathrm{C}$ peaks may be absent in many somatic tissues, leading to incorrect C-value calculations (Kron 2015; Trávníček et al. 2015).

Our results showed that the base of protocorms presented the highest proportion of cytotypes with higher ploidy levels. This feature was also observed in Phalaenopsis protocorms with FC (Chen et al. 2009) and by microscopic analysis of DAPI-stained nuclei (Jean et al. 2011). A possible explanation is that cells at the base of protocorms undergo cycles of endopolyploidy to increase their size. Orchid embryos have larger cells at the basal end (Yeung 2017), and a known effect of endopolyploidy is the increase in cell size (Rejlová et al. 2019). During symbiotic germination, only the cells of protocorms are colonized by mycorrhizal fungi hyphae (Chen et al. 2014), which also leads to nuclear hypertrophy (Peterson et al. 1998). The increase in cell size is perhaps one of the explanations for the higher cycle value of protocorm base, considering that such long-term coevolutionary morphological alterations are also maintained in asymbiotic germination (Yeung et al. 2019).

Root tips were the second-most endopolyploid tissue (Fig. 2, Table 1). Curiously, root tips were used for the definition of the diploid status of E. fulgens (Felix and Guerra 2010; Assis et al. 2013). As chromosome counts are performed with metaphase cells found in meristems, possibly, the endocycles 
occur in more differentiated root tissues, as it was meticulously detailed in the roots of Arabidopsis (Bhosale et al. 2018).

We detected differences in the cycle value between leaf tips and leaf bases. Surprisingly, leaf tips, which contain older and more differentiated cells compared to leaf bases, presented a smaller proportion of $16 \mathrm{C}$ cells (Fig. 2). The same endopolyploid pattern was reported in leaves of Spathoglottis plicata (Yang and Loh 2004).

Petals and labella have different patterns of endopolyploidy, which is remarkable considering that the labellum is a modified petal or tepal (Mondragón-Palomino and Theißen 2009). Labella are morphologically more complex than regular petals because they are involved in pollinator attraction. In Ophrys orchids, endoreduplication and partial endoreduplication detected in the labellum were correlated with cell size and complexity (Bateman et al. 2018).

\section{Comparative genome size estimation reveals the type of endoreduplication in E. fulgens}

There are only two Epidendrum spp. with known C-values: E. steinbachii, with 1.50 pg (Jones et al. 1998) and E. rigidum, with $1.21 \mathrm{pg}$ (Trávníček et al. 2015). The small variation in the estimated genome size of E. fulgens using the $2 \mathrm{C}$ peaks from different explants is an indication of $\mathrm{FC}$ analysis accuracy. Orchids are considered as a challenging group of plants for genome size estimation using flow cytometry (Trávníček et al. 2015), in part due to the recalcitrant nature of its tissues, which contain high levels of compounds that interfere with measurements and difficult properly nuclei isolation (Lee and Lin 2005). The present study shows that $E$. fulgens undergo the conventional type of endoreduplication, as the fluorescence relations between the peaks were always 2.0 , independent of the organ or tissue used for analysis.

\section{Tdz Can Induce Plbs From Diverse Orchid Tissues}

As far as we are aware, there is only one study reporting the successful micropropagation of orchids using flower parts as explants. Santana and Chaparro (1999) obtained PLB from Oncidium flower buds and Teixeira da Silva and Giang (2014) failed to induce PLB from different Phalaenopsis flower parts.

One of the reasons for using flower parts as explants in the present study, besides the difference in endopolyploidy, is the high availability of explants and the lower contamination rates. For the pollinia, the purpose was to obtain haploid cultures for subsequent homozygote development, which could be useful for genetic improvement. There are no studies exploring this biotechnology for orchids, although it is commonly used for many other plants.

The regeneration of orchids from leaf explants is relatively common. The leaf basal region showed the highest morphogenetic response rates in Phalaenopsis (Gow et al. 2009) and bromeliads (Alves et al. 2006; Dal Vesco et al. 2011; Scherer et al. 2013). However, for Oncidium orchids, PLBs were more frequently induced at the leaf tips (Chen and Chang 2001; Chung et al. 2005). Apparently, the morphogenetic response is species-specific. 
Our results show that $10 \mu \mathrm{M}$ TDZ is the most efficient concentration for PLB induction in $E$. fulgens leaf explants. Many other studies concluded that TDZ is an efficient PGR for PLB induction in many different orchid species and hybrids (Park et al. 2002; Park et al. 2003; Chen and Chang 2004; Chung et al. 2005), including in Epidendrum radicans (Chen and Chang 2002), which is closely related with $E$. fulgens. The preeminence of TDZ and other cytokinins over other PGR for PLB induction in orchids was recently reviewed in detail by (Cardoso et al. 2020). TDZ is chemically different from auxin and cytokinin, although it induces response-like activities from both (Guo et al. 2011). Recent studies suggest that its mechanism of action is far more complicated, including the stimuli from other PGR and regulatory signals (Dinani et al. 2018). Nevertheless, the present study results support the hypothesis that TDZ alone can induce PLB from different orchid tissues.

\section{PLB-regenerated plantlets may have a large rate of ploidy doubling, an important issue for the ornamental market and breeding}

According to the results from the present study, a higher proportion of ploidy doubled regenerants can be obtained from PLB induced from leaf explants than from protocorm bases. This is surprising and contradicts our initial hypothesis that explants with a higher proportion of endopolyploid cells have a higher probability to give origin to doubled ploidy regenerants. The plant regenerated from the root tip results do not fully reject that hypothesis, as the small sample size should be considered.

Less than $20 \%$ of the cells from the protocorm bases and ca. $25 \%$ from the leaf bases are $2 \mathrm{C}$, which means that, by chance, the other $75-80 \%$ of the cells could originate a PLB with altered ploidy level. The picture is not so simple considering the proportion of the other three cytotypes and that each cytotype might have differences in responsiveness for entering a specific morphogenetic pathway. Whether all cytotypes are capable of inducing PLBs could be only answered in a future study using some sort of cell sorting technique or protoplasts.

The results of the present study have important practical implications. When the objective of the micropropagation protocol is for cloning genetically superior plants, one should be aware that a considerable rate of double ploidy regenerants might be obtained. On the other hand, polyploid plants are especially valuable for the ornamental market to obtain novelties and overcome crossing barriers (Eeckhaut et al. 2018). Therefore, using endopolyploid explants might be used intentionally for genetic improvement.

Endopolyploidy of explants was already used as a tool for obtaining polyploid plants. Murashige and Nakano (1966) isolated polyploid cells from the pith of tobacco plants and regenerated polyploids. Polyploid azaleas were also successfully regenerated from endopolyploid petal margins (De Schepper et al. 2004). More recently, polyploid Phalaenopsis were obtained using the endopolyploid base of protocorms (Chen et al. 2009).

In terms of future research, it would be useful to extend the current findings by examining the ontogenesis of PLB induction from the different explants. Whether PLBs are induced from one cell or a group of cells 
from a specific cytotype will further help answer if ploidy duplication of regenerated plantlets results from a preexisting ploidy variation in explants or is the result of endoreduplication cycles occurring between stages of the morphogenetic pathway.

\section{Declarations}

Funding: Funding for this research was provided by the Conselho Nacional de Desenvolvimento Científico e Tecnológico - CNPq (Proc. 302798/2018-8, 407974/2018-0 and 140562/2016-8) and by Coordenação de Aperfeiçoamento de Pessoal de Nível Superior (CAPES).

Conflict of interests: The authors declare that they have no conflict of interest.

Ethics approval: All the experiments undertaken in this study comply with the current laws of the country where they were performed.

Author contributions: All authors contributed to the study's conception and design. Material preparation, data collection, and analysis were performed by Yohan Fritsche and Thiago S. Ornellas. The first draft of the manuscript was written by Yohan Fritsche and all authors commented on previous versions of the manuscript. All authors read and approved the final manuscript.

Data availability: Datasets generated during and/or analysed during the current study are available from the corresponding author on reasonable request.

\section{Acknowledgments}

We are grateful to Dr. Jaroslav Doležel for providing $P$. sativum seeds for FC analysis. We thank the Laboratório Multiusuário de Estudos em Biologia (LAMEB/UFSC) and the Laboratório Central de Microscopia Eletrônica (LCME/UFSC), of the Federal University of Santa Catarina for providing their infrastructure flow cytometry and microscopy analyses. We also thank Edison C. Medina for his guidance on SEM sample preparation. Funding for this research was provided by CNPq (Proc. 302798/2018-8, 407974/2018-0 and 140562/2016-8), and CAPES.

\section{References}

1. Alves GM, Dal Vesco LL, Guerra MP (2006) Micropropagation of the Brazilian endemic bromeliad Vriesea reitzii trough nodule clusters culture. Sci Hort 110:204-207. https://doi.org/10.1016/j.scienta.2006.06.014

2. Arditti J (2009) Micropropagation of orchids. John Wiley \& Sons, Hoboken

3. Assis FNM, Souza BCQ, Medeiros-Neto E, Pinheiro F, Silva AEB, Felix LP (2013) Karyology of the genus Epidendrum (Orchidaceae: Laeliinae) with emphasis on subgenus Amphiglottium and chromosome number variability in Epidendrum secundum. Bot J Linn Soc 172:329-344. https://doi.org/10.1111/boj.12045 
4. Bairu MW, Aremu AO, Van Staden J (2011) Somaclonal variation in plants: Causes and detection methods. Plant Growth Regul 63:147-173. https://doi.org/10.1007/s10725-010-9554-x

5. Barow M (2006) Endopolyploidy in seed plants. BioEssays 28(3):271-281. https://doi.org/10.1002/bies.20371

6. Barow M, Jovtchev G (2007) Endopolyploidy in Plants and its Analysis by Flow Cytometry. In: Dolezel J, Greilhuber J, Suda J (eds) Flow Cytometry with Plant Cells Analysis of Genes, Chromosomes and Genomes, 1st edn. Wiley, New York, pp 349-370

7. Barow M, Meister A (2003) Endopolyploidy in seed plants is differently correlated to systematics, organ, life strategy and genome size. Plant, Cell Environ 26:571-584. https://doi.org/10.1046/j.13653040.2003.00988.x

8. Bateman RM, Guy JJ, Rudall PJ, Leitch IJ, Pellicer J, Leitch AR (2018) Evolutionary and functional potential of ploidy increase within individual plants: Somatic ploidy mapping of the complex labellum of sexually deceptive bee orchids. Ann Botany 122:133-150. https://doi.org/10.1093/aob/mcy048

9. Bhosale R, Boudolf V, Cuevas F et al (2018) A spatiotemporal DNA endoploidy map of the Arabidopsis root reveals roles for the endocycle in root development and stress adaptation. Plant Cell 30:2330-2351. https://doi.org/10.1105/tpc.17.00983

10. Botelho FBS, Rodrigues CS, Bruzi AT (2015) Ornamental plant breeding. Ornamental Horticulture 21(1):9-16. https://doi.org/10.14295/rbho.v21i1.770

11. Brown SC, Bourge M, Maunoury N et al (2017) DNA Remodeling by strict partial endoreplication in orchids, an original process in the plant Kingdom. Genome Biol Evol 9:1051-1071. https://doi.org/10.1093/gbe/evx063

12. Cardoso JC, Zanello CA, Chen JT (2020) An overview of orchid protocorm-like bodies: Mass propagation, biotechnology, molecular aspects, and breeding. Int J Mol Sci 21(3):985. https://doi.org/10.3390/ijms21030985

13. Chen JT, Chang WC (2001) Effects of auxins and cytokinins on direct somatic embryogenesis on leaf explants of Oncidium 'Gower Ramsey'. Plant Growth Regul 34(2):229-232. https://doi.org/10.1023/A:1013304101647

14. Chen J, Wang H, Liu SS, Li YY, Guo SX (2014) Ultrastructure of symbiotic germination of the orchid Dendrobium officinale with its mycobiont, Sebacina sp. Aust J Bot 62:229-234. https://doi.org/10.1071/BT14017

15. Chen JT, Chang WC (2006) Direct somatic embryogenesis and plant regeneration from leaf explants of Phalaenopsis amabilis. Biol Plant 50:169-173. https://doi.org/10.1007/s10535-006-0002-8

16. Chen JT, Chang WC (2004) Induction of repetitive embryogenesis from seed-derived protocorms of Phalaenopsis amabilis var. Formosa Shimadzu. In Vitro Cellular \& Developmental Biology - Plant 40:290-293. https://doi.org/10.1079/IVP2003527

17. Chen LR, Chen JT, Chang WC (2002) Efficient production of protocorm-like bodies and plant regeneration from flower stalk explants of the sympodial orchid Epidendrum radicans. In Vitro 
Cellular \& Developmental Biology - Plant 38:441-445. https://doi.org/10.1079/IVP2002315

18. Chen WH, Tang CY, Kao YL (2009) Ploidy doubling by in vitro culture of excised protocorms or protocorm-like bodies in Phalaenopsis species. Plant Cell, Tissue and Organ Culture (PCTOC) 98:229-238. https://doi.org/10.1007/s11240-009-9557-3

19. Chung HH, Chen JT, Chang WC (2005) Cytokinins induce direct somatic embryogenesis of Dendrobium Chiengmai Pink and subsequent plant regeneration. In Vitro Cellular \& Developmental Biology - Plant 41:765-769. https://doi.org/10.1079/IVP2005702

20. Dal Vesco LL, Stefenon VM, Welter LJ, Scherer RF, Guerra MP (2011) Induction and scale-up of Billbergia zebrina nodule cluster cultures: Implications for mass propagation, improvement and conservation. Sci Hort 128:515-522. https://doi.org/10.1016/j.scienta.2011.02.018

21. De Schepper S, Leus L, Eeckhaut T, Bockstaele EV, Debergh P, De Loose M (2004) Somatic polyploid petals: regeneration offers new roads for breeding Belgian pot azaleas. Planr Cell Tissue Organ Cult 76:183-188. https://doi.org/10.1023/B:TICU.0000007284.43939.0f

22. Dewir YH, Nurmansyah, Naidoo Y, Teixeira da Silva JA (2018) Thidiazuron-induced abnormalities in plant tissue cultures. Plant Cell Rep 37:1451-1470. https://doi.org/10.1007/s00299-018-2326-1

23. Dinani ET, Shukla MR, Turi CE et al (2018) Thidiazuron: Modulator of Morphogenesis In Vitro. In: Ahmad N, Faisal M (eds) Thidiazuron: From Urea Derivative to Plant Growth Regulator, 1 st edn. Springer, Singapore, pp 1-36. https://doi.org/10.1007/978-981-10-8004-3_1

24. Doležel J, Bartoš J (2005) Plant DNA flow cytometry and estimation of nuclear genome size. Ann Botany 95:99-110. https://doi.org/10.1093/aob/mci005

25. Doležel J, Bartos J, Voglmayr H, Greilhuber J (2003) Nuclear DNA content and genome size of trout and human. Cytometry Part A: the journal of the International Society for Analytical Cytology 51:127-128. https://doi.org/10.1002/cyto.a.10013

26. Edgar B, Zielke N, Gutierrez C (2014) Endocycles: a recurrent evolutionary innovation for post-mitotic cell growth. Nat Rev Mol Cell Biol 15:197-210. https://doi.org/10.1038/nrm3756

27. Eeckhaut T, Van der Veken J, Dhooghe E, Leus L, Van Laere K, Van Huylenbroeck J (2018) Ploidy Breeding in Ornamentals. In: Van Huylenbroeck J (ed) Ornamental Crops. Handbook of Plant Breeding, vol 11. Springer, Cham, pp 145-173. https://doi.org/10.1007/978-3-319-90698-0_7

28. Felix LP, Guerra M (2010) Variation in chromosome number and the basic number of subfamily Epidendroideae (Orchidaceae). Bot J Linn Soc 163:234-278. https://doi.org/10.1111/j.10958339.2010.01059.x

29. Fox J, Weisberg S (2019) An R Companion to Applied Regression, Third edition. Sage, Thousand Oaks CA. https://socialsciences.mcmaster.ca/jfox/Books/Companion/

30. Fukai S, Hasegawa A, Goi M (2002) Polysomaty in Cymbidium. HortScience 37:1088-1091. https://doi.org/10.21273/HORTSCI.37.7.1088

31. Galbraith DW, Harkins KR, Maddox JM, Ayres NM, Sharma DP, Firoozabady E (1983) Rapid flow cytometric analysis of the cell cycle in intact plant tissues. Science 220(4601):1049-1051. https://doi.org/10.1126/science.220.4601.1049 
32. Gow WP, Chen JT, Chang WC (2009) Effects of genotype, light regime, explant position and orientation on direct somatic embryogenesis from leaf explants of Phalaenopsis orchids. Acta Physiol Plant 31:363-369. https://doi.org/10.1007/s11738-008-0243-6

33. Guo B, Abbasi BH, Zeb A, Xu LL, Wei YH (2011) Thidiazuron: a multi-dimensional plant growth regulator. Afr J Biotechnol 10(45):8984-9000. https://doi.org/10.5897/AJB11.636

34. Ho TT, Kwon AR, Yoon YJ, Paek KY, Park SY (2016) Endoreduplication level affects flower size and development by increasing cell size in Phalaenopsis and Doritaenopsis. Acta Physiol Plant 38(8):111. https://doi.org/10.1007/s11738-016-2222-7

35. Hsieh KT, Liu SH, Wang IW, Chen LJ (2020) Phalaenopsis orchid miniaturization by overexpression of OsGA2ox6, a rice GA2-oxidase gene. Botanical Studies 61:10. https://doi.org/10.1186/s40529-02000288-0

36. Jean GT, Kao YL, Tang CY, Chen WH (2011) Distribution of nuclei of different ploidy levels during ovule, seed and protocorm development in Phalaenopsis aphrodite subsp. formosana (Orchidaceae). American Journal of Plant Sciences 2(03):325. http://dx.doi.org/10.4236/ajps.2011.23037

37. Jones W, Kuehnle AR, Arumuganathan K (1998) Nuclear DNA Content of 26 Orchid (Orchidaceae) Genera with Emphasis on Dendrobium. Ann Botany 82:189-194. https://doi.org/10.1006/anbo.1998.0664

38. Kerbauy GB, Estelita MEM (1996) Formation of protocorm-like bodies from sliced root apexes of Clowesia warscewiczii. Revista Brasileira de Fisiologia Vegetal 8(2):157-159

39. Kron P (2015) Endopolyploidy, genome size, and flow cytometry. Cytometry Part A 87:887-889. https://doi.org/10.1002/cyto.a.22718

40. Laimbeer FPE, Holt SH, Makris M et al (2017) Protoplast isolation prior to flow cytometry reveals clear patterns of endoreduplication in potato tubers, related species, and some starchy root crops. Plant Methods 13:1-10. https://doi.org/10.1186/s13007-017-0177-3

41. Lee HC, Lin TY (2005) Isolation of plant nuclei suitable for flow cytometry from recalcitrant tissue by use of a filtration column. Plant Mol Biol Rep 23:53-58. https://doi.org/10.1007/BF02772646

42. Lee HO, Davidson JM, Duronio RJ (2009) Endoreplication: polyploidy with purpose. Genes Dev 23(21):2461-2477. http://www.genesdev.org/cgi/doi/ 10.1101/gad.1829209

43. Leitch IJ, Dodsworth S (2017) Endopolyploidy in Plants. John Wiley \& Sons, Chichester. https://doi.org/10.1002/9780470015902.a0020097.pub2

44. Leitch IJ, Johnston E, Pellicer J, Hidalgo O, Bennett MD (2019) Plant C-value database, release 7.1. https://cvalues.science.kew.org/

45. Li S, Liu L, Li T et al (2019) The distribution pattern of endopolyploidy in maize. Theor Appl Genet 132:1487-1503. https://doi.org/10.1007/s00122-019-03294-4

46. Lim WL, Loh C-S (2003) Endopolyploidy in Vanda Miss Joaquim (Orchidaceae). New Phytol 159:279-287. https://doi.org/10.1046/j.1469-8137.2003.00797.x 
47. Liu YC, Yeh CW, Chung JD, Tsai CY, Chiou CY, Yeh KW (2019) Petal-specific RNAi-mediated silencing of the phytoene synthase gene reduces xanthophyll levels to generate new Oncidium orchid varieties with white-colour blooms. Plant Biotechnol J 17(11):2035-2037. https://doi.org/doi:

10.1111/pbi.13179

48. Mondragón-Palomino M, Theißen G (2009) Why are orchid flowers so diverse? Reduction of evolutionary constraints by paralogues of class B floral homeotic genes. Ann Botany 104:583-594. https://doi.org/10.1093/aob/mcn258

49. Murashige T, Nakano R (1966) Tissue culture as a potential tool in obtaining polyploid plants. $\mathrm{J}$ Hered 57:115-118. https://doi.org/10.1093/oxfordjournals.jhered.a107486

50. Murashige T, Skoog F (1962) A Revised Medium for Rapid Growth and Bio Assays with Tobacco Tissue Cultures. Physiologia Plantarum 15:474-497.https://doi.org/10.1111/j.13993054.1962.tb08052.xOtto, F. (1990). DAPI staining of fixed cells for high-resolution flow cytometry of nuclear DNA. In: Darzynkiewicz Z, Crissman HA (eds) Methods in cell biology 33, 1st edn. Academic Press, Cambridge, pp 105-110. https://doi.org/10.1016/S0091-679X(08)60516-6

51. O'Brien T, Feder N, McCully ME (1964) Polychromatic staining of plant cell walls by toluidine blue 0 . Protoplasma 59:368-373. https://doi.org/10.1007/BF01248568

52. Park SY, Murthy HN, Paek KY (2003) Protocorm-like body induction and subsequent plant regeneration from root tip cultures of Doritaenopsis. Plant Sci 164:919-923. https://doi.org/10.1016/S0168-9452(03)00019-0

53. Park SY, Yeung EC, Chakrabarty D, Paek KY (2002) An efficient direct induction of protocorm-like bodies from leaf subepidermal cells of Doritaenopsis hybrid using thin-section culture. Plant Cell Rep 21:46-51. https://doi.org/10.1007/s00299-002-0480-x

54. Peterson RL, Uetake Y, Zelmer C (1998) Fungal symbioses with orchid protocorms. Symbiosis 25:2955

55. Picolotto DRN, de Paiva Neto VB, de Barros F, Padilha DRC, Cruz ACF, Otoni WC (2017) Micropropagation of Cyrtopodium paludicolum (Orchidaceae) from root tip explants. Crop Breeding and Applied Biotechnology 17:191-197. https://doi.org/10.1590/1984-70332017v17n3a30

56. Rejlová L, Chrtek J, Trávníček P, Lučanová M, Vít P, Urfus T (2019) Polyploid evolution: The ultimate way to grasp the nettle. PLoS ONE 14:1-24. https://doi.org/10.1371/journal.pone.0218389

57. Roy J, Naha S, Majumdar M, Banerjee N (2007) Direct and callus-mediated protocorm-like body induction from shoot-tips of Dendrobium chrysotoxum Lindl. Planr Cell Tissue Organ Cult 90:31-39. https://doi.org/10.1007/s11240-007-9244-1. Orchidaceae

58. Santana GE, Chaparro K (1997) Clonal propagation of Oncidium through the culture of floral buds. In International Symposium on Cut Flowers in the Tropics 482 (pp. 315-320). https://doi.org/10.17660/ActaHortic.1999.482.46

59. Scherer RF, Garcia AC, Fraga HP, de Dal Vesco F, Steinmacher LL, Guerra DA MP (2013) Nodule cluster cultures and temporary immersion bioreactors as a high performance micropropagation 
strategy in pineapple (Ananas comosus var. comosus). Sci Hort 151:38-45.

https://doi.org/10.1016/j.scienta.2012.11.027

60. Teixeira da Silva JA, Tanaka M (2006) Multiple Regeneration Pathways via Thin Cell Layers in Hybrid Cymbidium (Orchidaceae). J Plant Growth Regul 25:203-210. https://doi.org/10.1007/s00344-0050104-0

61. Teixeira da Silva JA, Giang DTT (2014) Unsuccessful in vitro regeneration from Phalaenopsis (Orchidaceae) flowers. The All Results Journals Biology 5:18-22

62. Teoh SB (1984) Polyploid spore formation in diploid orchid species. Genetica 63:53-59. https://doi.org/10.1007/BF00137465

63. Trávníček P, Čertner M, Ponert J, Chumová Z, Jersáková J, Suda J (2019) Diversity in genome size and GC content shows adaptive potential in orchids and is closely linked to partial endoreplication, plant life-history traits and climatic conditions. New Phytol 224:1642-1656. https://doi.org/10.1111/nph.15996

64. Trávníček P, Ponert J, Urfus T, Jersáková J, Vrana J, Hřibová E, Doležel J, Suda J (2015) Challenges of flow-cytometric estimation of nuclear genome size in orchids, a plant group with both wholegenome and progressively partial endoreplication. Cytometry Part A 87(10):958-966. https://doi.org/10.1002/cyto.a.22681

65. Venables WN, Ripley BD (2002) Modern Applied Statistics with S, 4th edn. Springer, New York. https://www.stats.ox.ac.uk/pub/MASS4/

66. Voges JG, Benevenuto RF, Fritsche Y, Guerra MP (2014) Protocorm development of Epidendrum fulgens (Orchidaceae) in response to different saline formulations and culture conditions. Acta Scientiarum Biological Sciences 36:287. https://doi.org/10.4025/actascibiolsci.v36i3.21079

67. Wickham H (2016) ggplot2: Elegant Graphics for Data Analysis. Springer-Verlag, New York. https://ggplot2.tidyverse.org

68. Yang M, Loh C-S (2004) Systemic endopolyploidy in Spathoglottis plicata (Orchidaceae) development. BMC Cell Biol 5:1-8. https://doi.org/10.1186/1471-2121-5-33

69. Yeung EC (2017) A perspective on orchid seed and protocorm development. Botanical Studies 58(1):1-14. https://doi.org/10.1186/s40529-017-0188-4

70. Yeung EC, Li YY, Lee YI (2019) An overview of the life of an orchid protocorm - a developmental perspective. Acta Hort 1262:13-22. https://doi.org/10.17660/ActaHortic.2019.1262.3

\section{Figures}




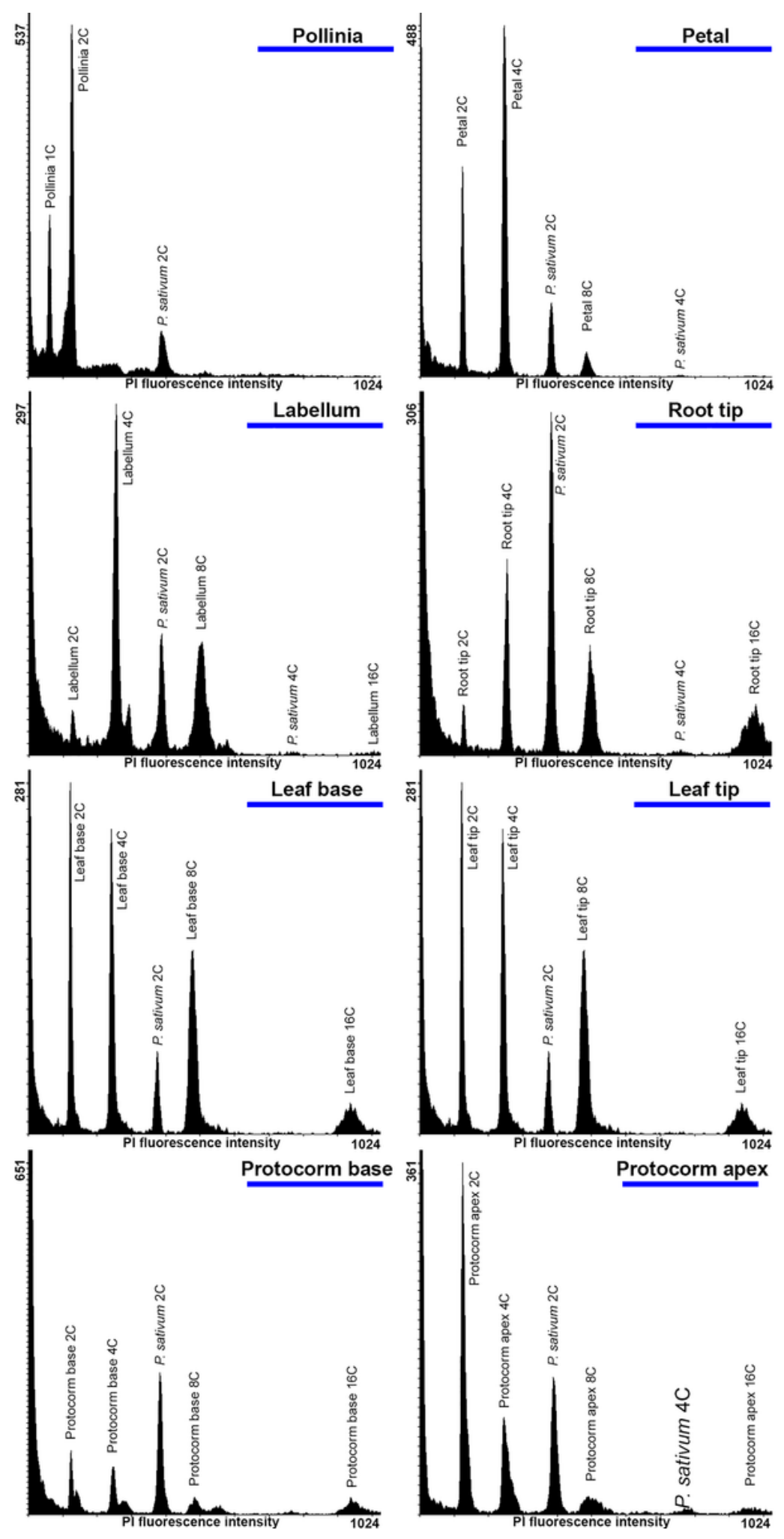

Figure 1

Linear scale histograms of relative propidium iodine $(\mathrm{PI})$ fluorescence intensity obtained after flow cytometry analysis of stained nuclei isolated from different organs and tissues of Epidendrum fulgens 


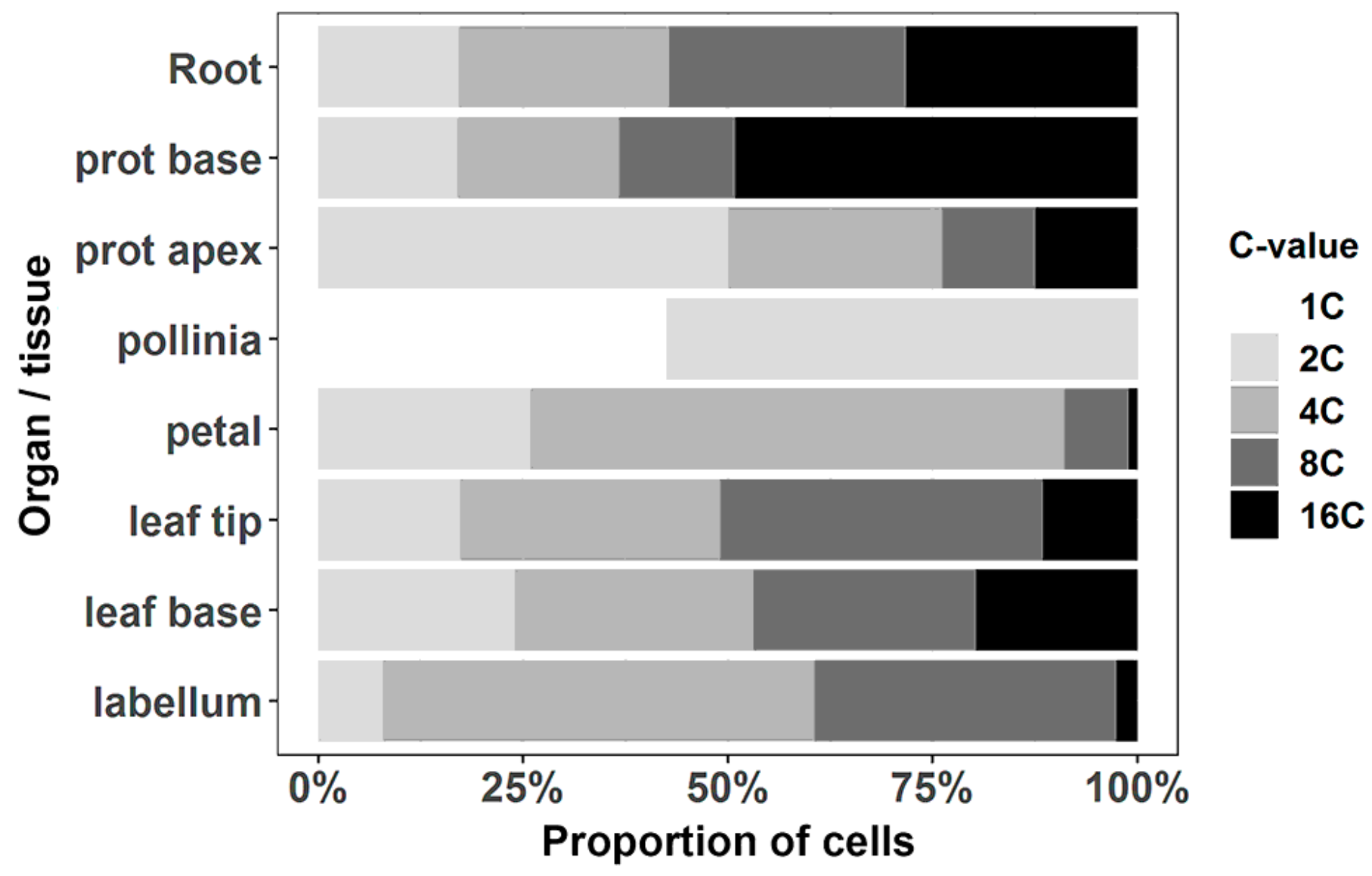

Figure 2

Proportion of cells with different DNA C content on different organs and tissues of Epidendrum fulgens 

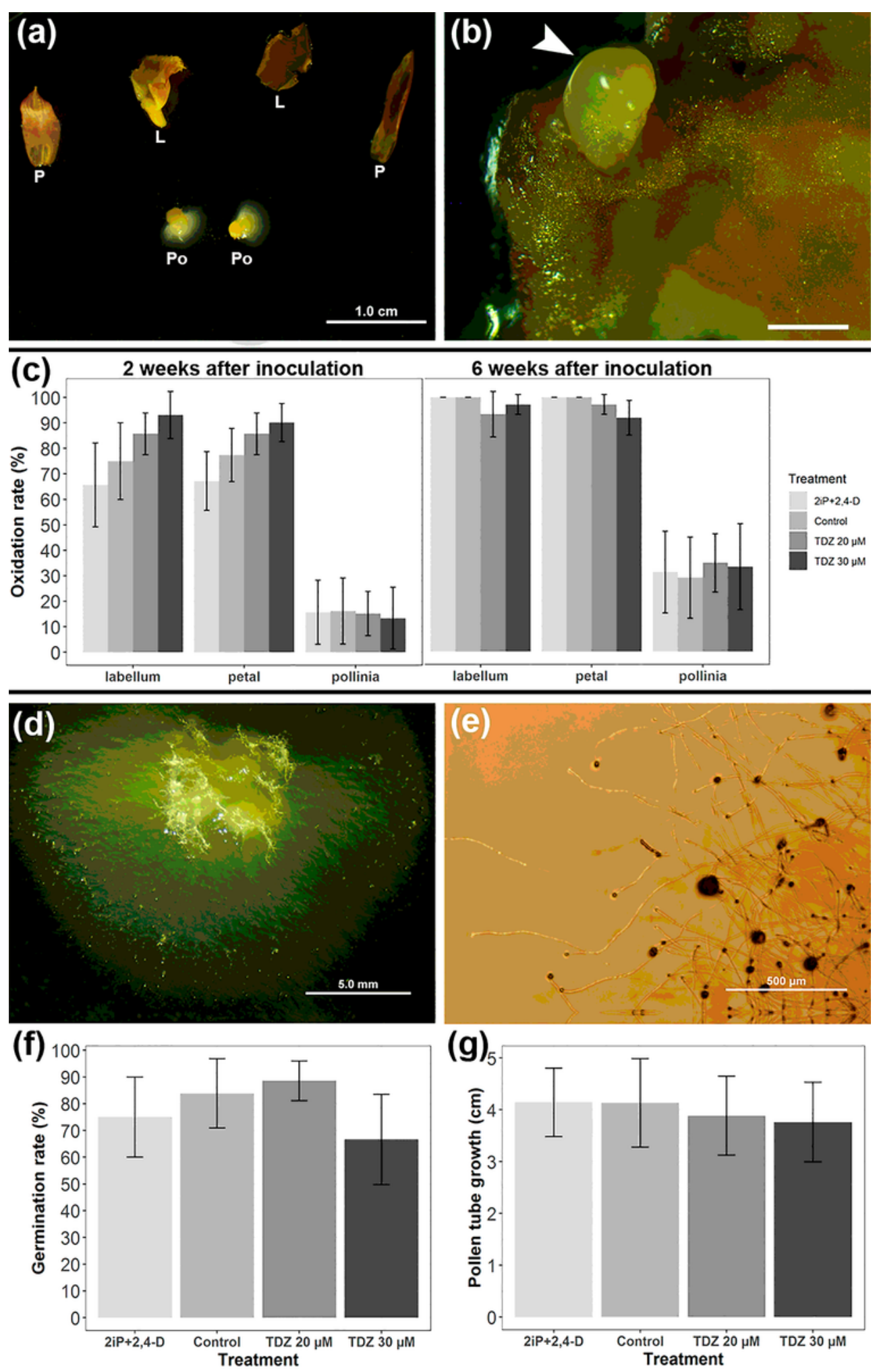

\section{Figure 3}

PLB induction using Epidendrum fulgens flower parts as explants. a) Petals (P), Labella (L) and Pollinia (Po) 1 week after inoculation on MS/2 medium supplemented with $20 \mu \mathrm{M}$ TDZ. b) A primary PLB induced from the labellum. c) Explant oxidation rates two (left) and six (right) weeks after inoculation. d) A germinated pollinia 4 weeks after inoculation in MS/2 medium without PGR. e) Details of germinating pollen grains seen under the microscope. f) Pollinia germination rate in media supplemented with 
different PGR. g) Pollen tube growth in media supplemented with different PGR. Error bars in (c), (f) and (g) are confidence intervals $(p=0.05)$
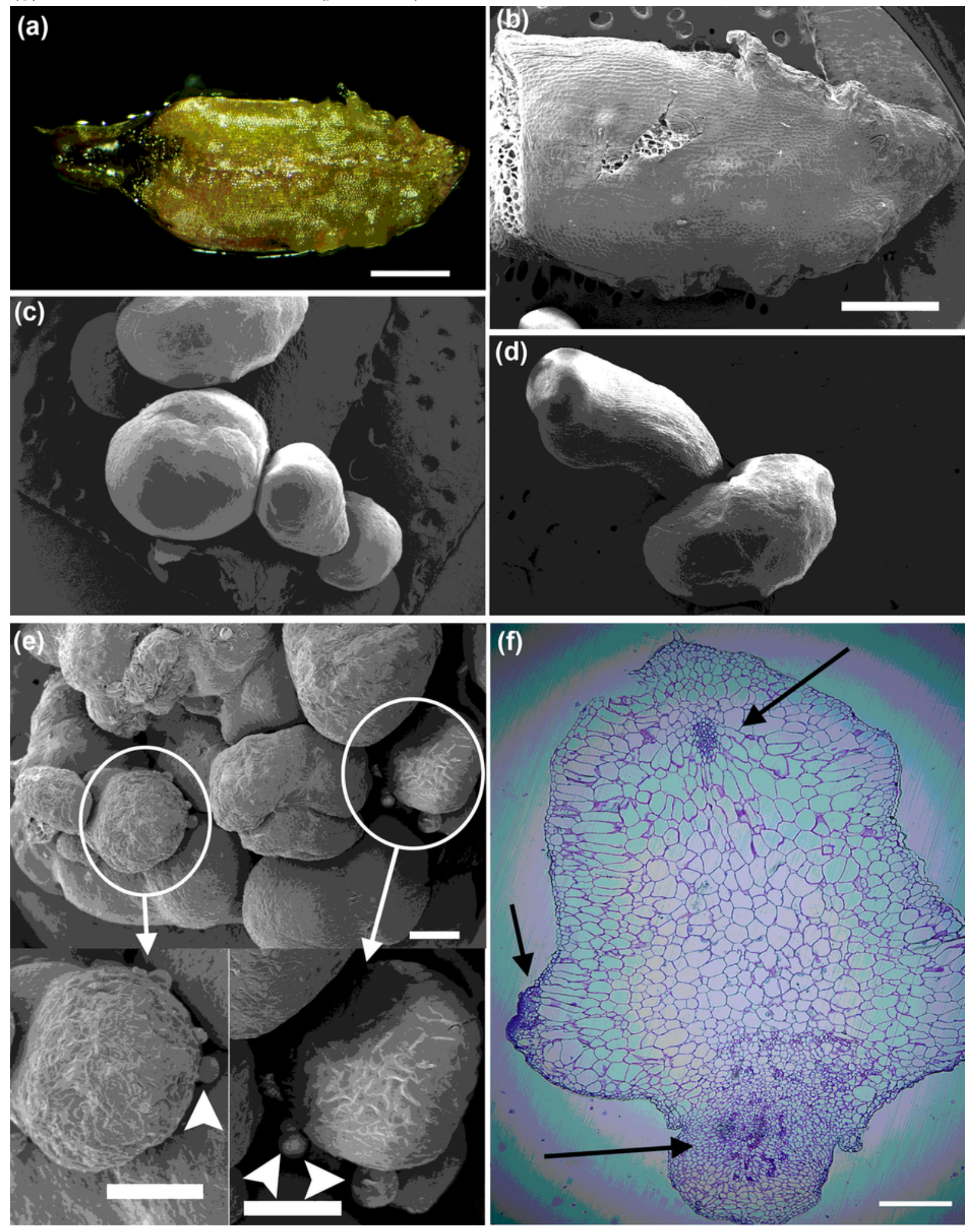

Figure 4

Morphological and histoanatomical features of Epidendrum fulgens protocorm-like bodies (PLB). a) A leaf explant after 4 weeks of inoculation in MS medium supplemented with $10 \mu \mathrm{M}$ Thidiazuron showing initial PLB induction. Scale bar $=1 \mathrm{~mm}$. b) Scanning electron micrograph of the same explant (a) 
showing details of the initial PLB induction from the epidermis leaf tissue. Scale bar $=1 \mathrm{~mm}$. c) Globular shaped primary PLB after 4 weeks ofinoculation. Scale bar $=1 \mathrm{~mm}$. d) Primary PLB elongating without leaf primordia formation. Scale bar $=1 \mathrm{~mm}$. e) Secondary PLB formation (arrowheads) from primary PLB. Bottom images are magnified details from the main micrograph. Scale bars $=500 \mu \mathrm{m} . \mathrm{f}$ ) Histoanatomical feature of a primary PLB stained with toluidine blue. The PLB is surrounded by a welldefined cell layer (peridermis). The central meristem (upper most arrow) and secondary meristematic regions (arrows) are characterized by small cells with prominent nuclei that are intensively stained by toluidine blue 


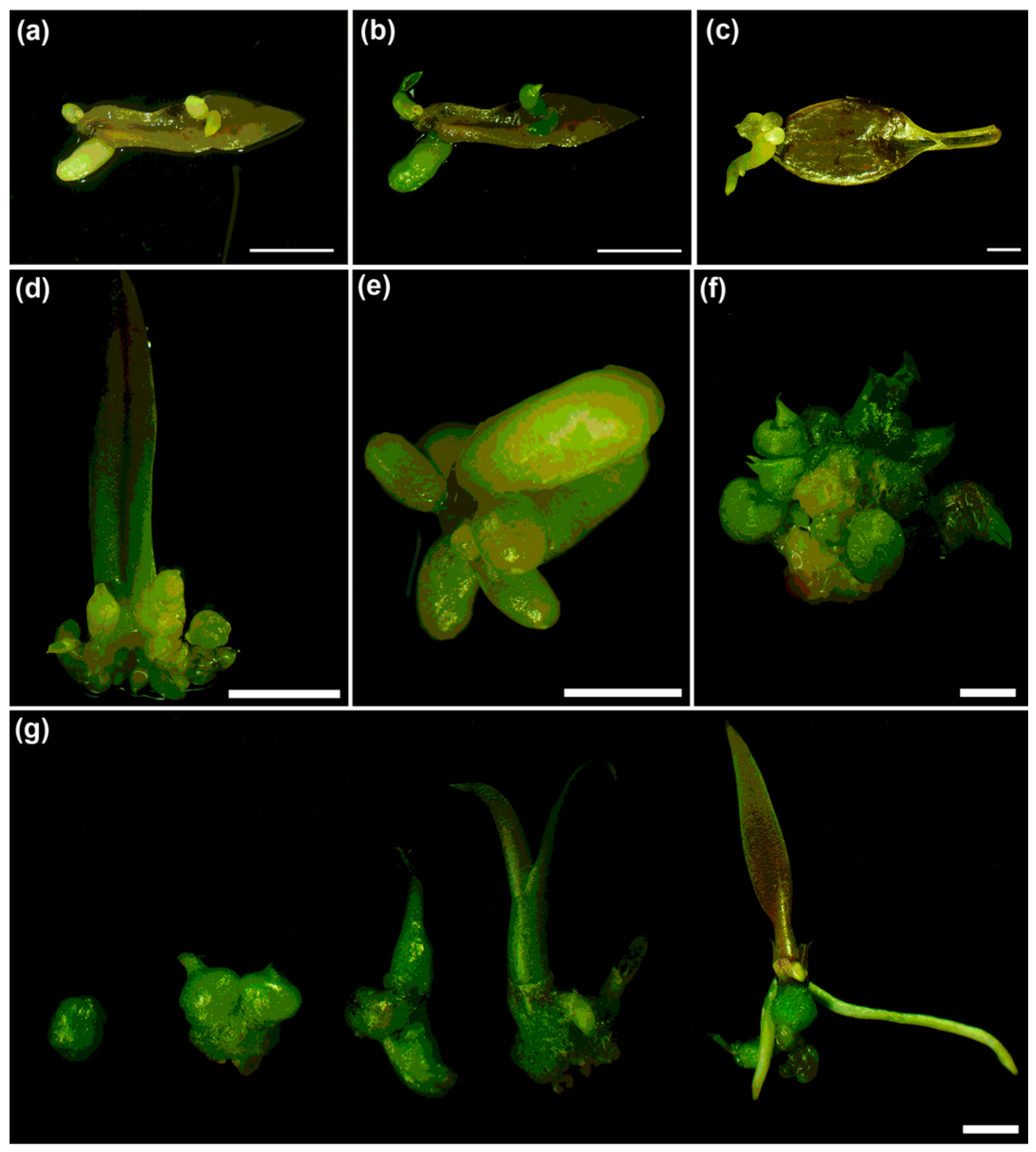

\section{Figure 5}

PLB induction and plantlet regeneration from leaf explants. $a-b)$ PLB induced at the leaf base and in the top of the leaf blade, before (a) and after (b) light exposition. Scale bars $=5 \mathrm{~mm} c$ ) PLB induced at the leaf tip. Scale bar $=2 \mathrm{~mm}$. d) A responsive leaf explant with many PLB at the base region. Scale bar $=5$ $\mathrm{mm}$. e) A PLB cluster before light exposition. Scale bar $=2 \mathrm{~mm}$. f) A compact cluster of PLB after 2 weeks of transference to PGR-free medium and light exposition. Note the formation of leaf primordia. Scale bar 
$=2 \mathrm{~mm} . \mathrm{g}$ ) The detailed process of plant regeneration from PLB, from the globular stage (left) to plantlet with fully expanded leaf and adventitious roots (right). Scale bar $=0.5 \mathrm{~cm}$
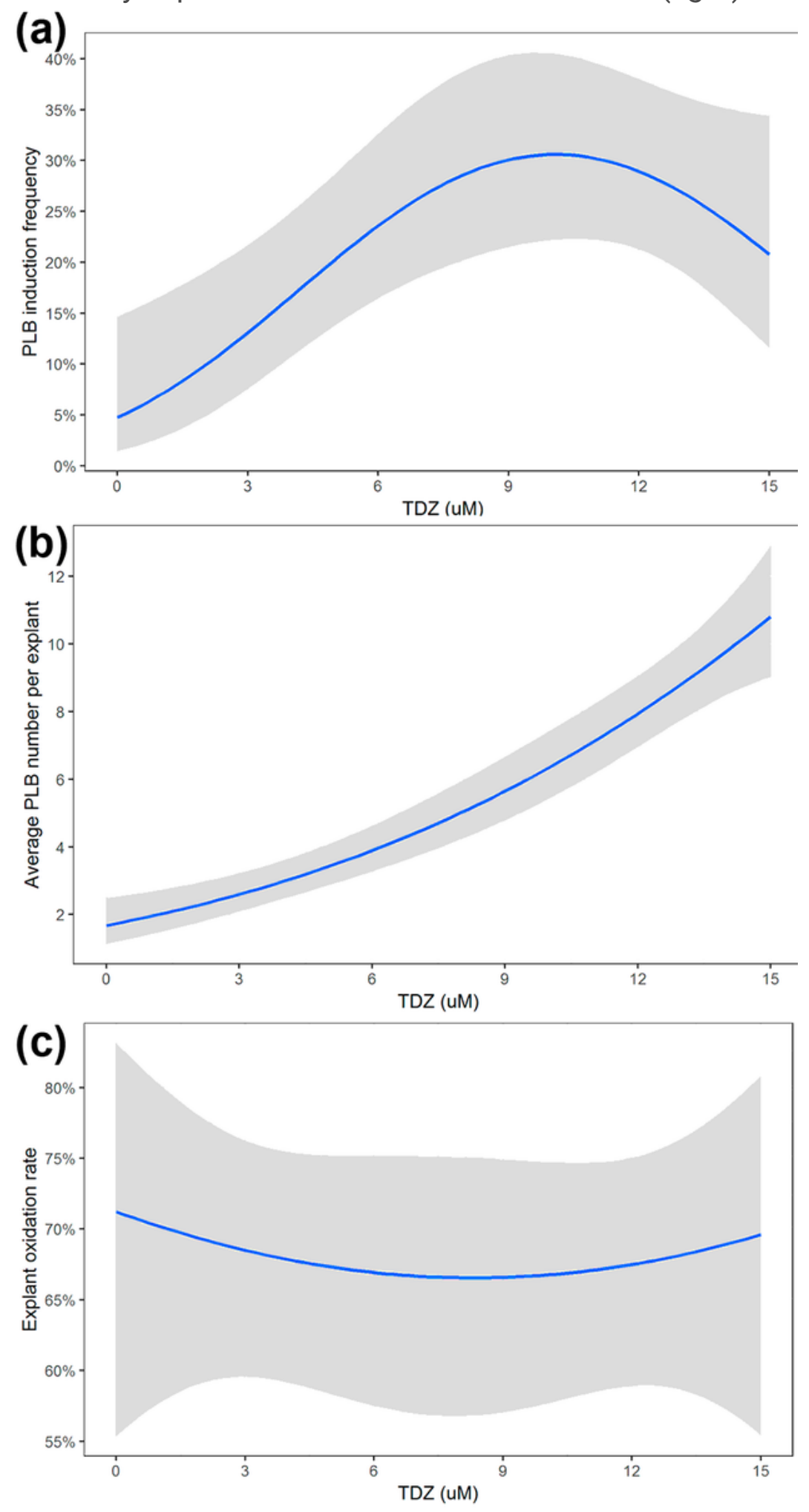

Figure 6

Estimated trends for PLB induction frequency (a), average number of PLB (b), and explant oxidation rates (c) from Epidendrum fulgens leaf explants under increasing concentrations of TDZ $(0 \mu \mathrm{M}, 1 \mu \mathrm{M}, 3 \mu \mathrm{M}, 9$ 
$\mu \mathrm{M}, 12 \mu \mathrm{M}$, and $15 \mu \mathrm{M})$. Data collected after 8 weeks of culture. Shaded bands indicate $95 \%$ confidence envelopes
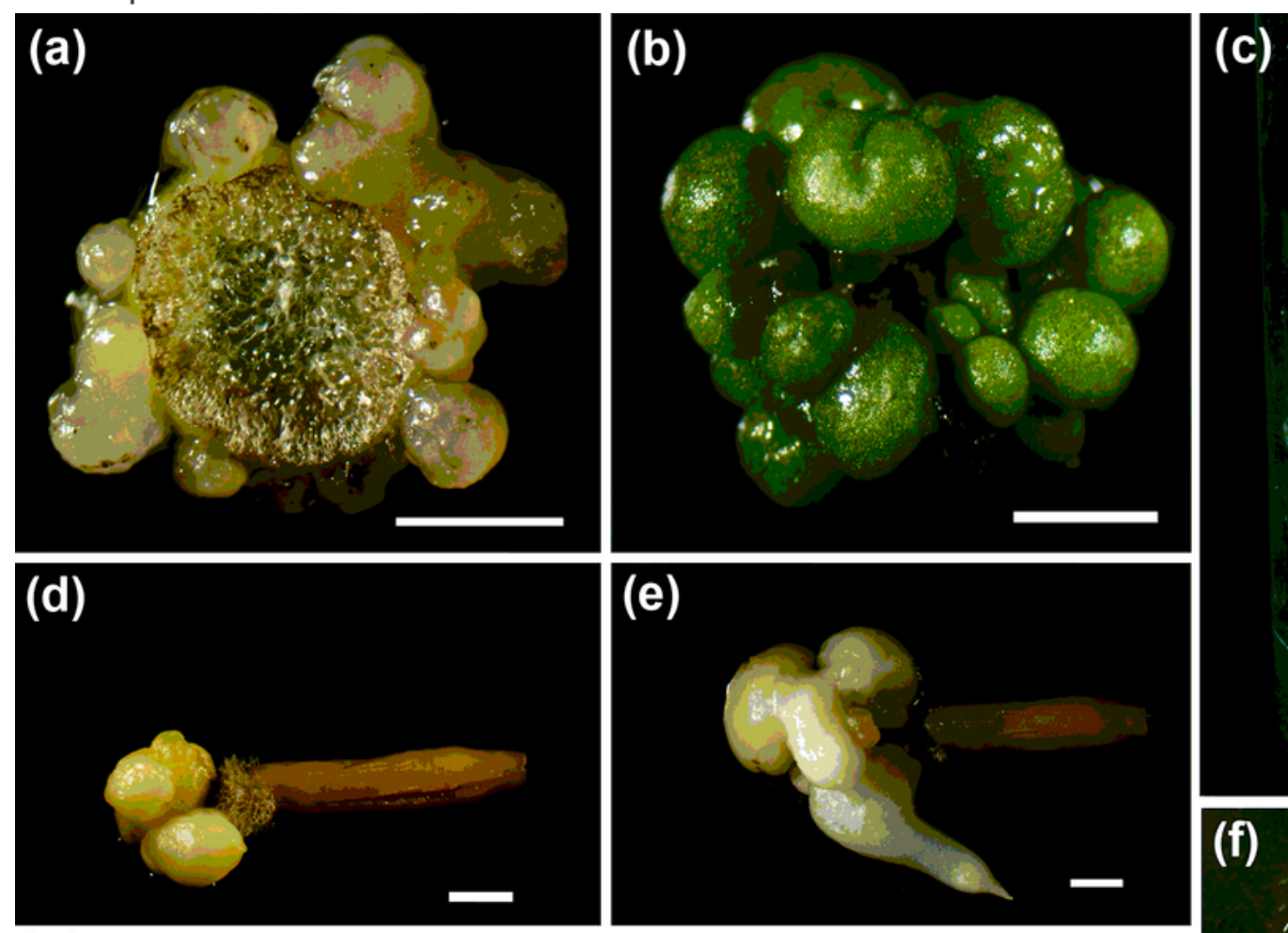

(g)
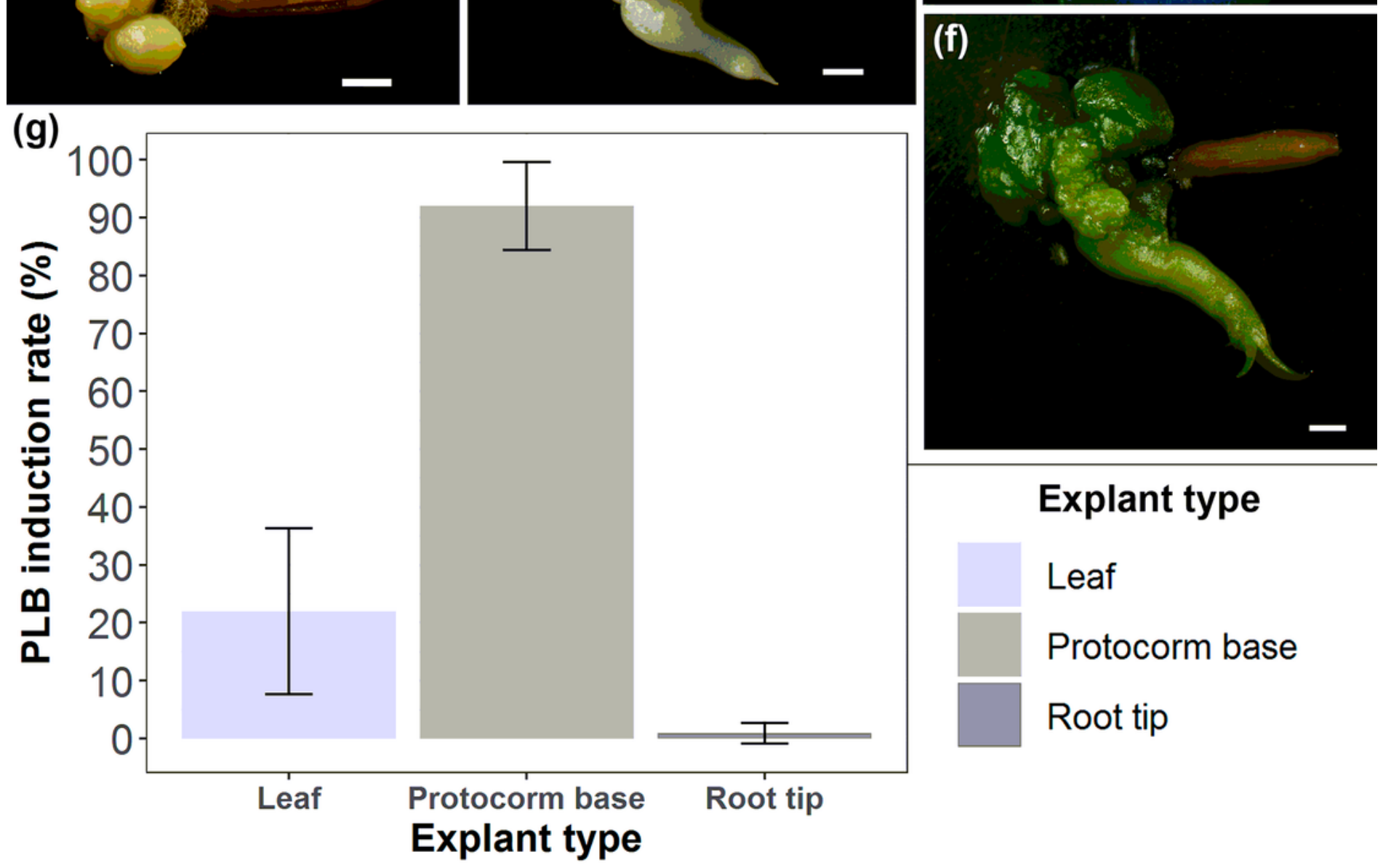

\section{Explant type}

Leaf

Protocorm base

Root tip

Figure 7

PLBs induction and plant regeneration from protocorm bases and root tips. a) A $1 \mathrm{~mm}$ width TCL from the protocorm base 4 weeks after inoculation on MS/2 medium supplemented with $10 \mu \mathrm{M}$ TDZ. Note that the globular white-color PLB are induced directly from the epidermal tissue. b) PLBs acquire a dark green 
color 2 week after transfer to PGR-free medium and light exposition. c) Plantlets obtained from a TCL from the base of a protocorm. d) A root tip explant with PLB forming at the apical meristem region. Note the velamen and root hairs close to the PLB. e) PLB started to elongate before transfer to light. f) A shoot with leaf primordia formed 9 months after transfer to PGR-free medium and light exposition. g) PLB induction rate comparison between leaves, root tips and protocorm bases in MS/2 medium supplemented with $10 \mu \mathrm{M}$ TDZ. Bars are confidence intervals $(p=0.05)$
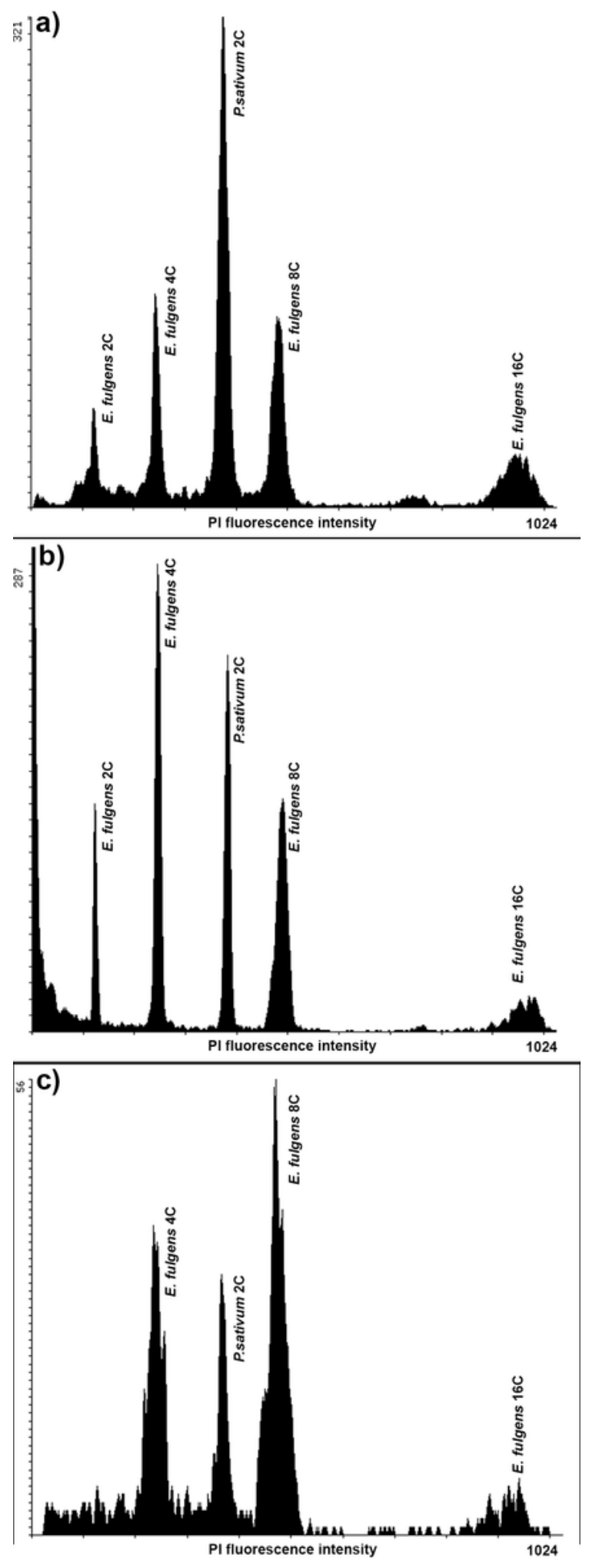

Figure 8 
Cytogenetic stability of Epidendrum fulgens PLB-regenerated plants from explants with contrasting endopolyploid patterns. Histograms of relative fluorescence intensity (linear scale) obtained after the analysis of propidium iodide $(\mathrm{PI})$ stained nuclei isolated from leaves of Epidendrum fulgens in vitro plantlets using Pisum sativum 'Ctirad' as an internal reference standard. a) Control plants obtained from asymbiotic seed germination. b) A representative histogram of a cytogenetically stable plantlet regenerated from a PLB induced from a leaf explant. c) A representative histogram of a plantlet regenerated from a PLB induced from a protocorm base, which presents double ploidy level in relation to control plants. Note the absence of the fluorescence peak from the $2 \mathrm{C}$ cells 